Arab World English Journal (AWEJ) Volume 9. Number 1. March 2018

DOI: https://dx.doi.org/10.24093/awej/vol9no1.16

Pp. 220-232

\title{
The Effect of the Use of Technology on the nature of Teacher's Profession
}

\author{
Sally Kondos \\ University of Exeter, United Kingdom \\ $\&$ \\ Center for English Proficiency, American University in Dubai \\ United Arab Emarites
}

\section{Abstract ;}

Educational programmes have recognized the growing need to use computers in the classes as it presents unprecedented challenges that help the students to acquire an inquiring, critical and creative mind to capitalize on the opportunities driven by the growth of information, knowledge and technology. The computer knowledge has begun influencing student's learning experience for more than 25 years ago, but it was in a moderate manner (Cuban, 2001). However, the past decade has witnessed major trend toward integrating computer technology in all the language classes. The integration has increased because the computer technology represents an accessible and instant information, enormous potential for interactivity and media-rich communication, as well as educational tools which engage the students in the classroom (Mouza, 2002). Undoubtedly the recent advancement in information technology and computer usage in the classroom is rapidly transforming the environment of the classroom. The teachers cannot ignore the reality the today's classroom must provide technology-supported learning (Angers \& Machtmes, 2005). Being prepared to integrate the technology in the classroom has become a paramount skill in every teacher's professional repertoires. The traditional role of the teacher as the center of the schooling is changing recently with all the introduction of the new technologies in the classroom. One of the effects of the new technologies is the decentralization of teachers in the learning environment (Damrian, 1998). This introduces a very valid point of how the teaching profession will change in the era of digital technologies. What is the role of the teacher in a classroom where he/she is no longer the only source of knowledge? How can he/ she teach effectively in a class, where every student has his/her computer and can Google any piece of information? The following study will investigate the effect of the implementation of the technology in the English as a foreign language (EFL) classes on the nature of the teachers' profession.

Keywords: Digital immigrants, digital natives, integration, new technologies Technologyenhanced environment, Professionalism,

Cite as: Kondos, S. (2018). The Effect of the Use of Technology on the nature of Teacher's Profession. Arab World English Journal, 9 (1). DOI: https://dx.doi.org/10.24093/awej/vol9no1.16 